\title{
Kilka uwag na temat telemedycyny
}

\author{
A few comments about telemedicine
}

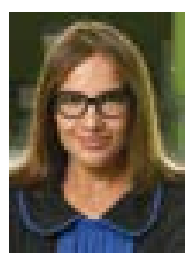

\author{
Kamila Kocańda \\ Instytut Nauk Medycznych Uniwersytetu Jana Kochanowskiego w Kielcach \\ Wojewódzki Szpital Zespolony w Kielcach
}

\section{Streszczenie}

Udzielanie porad lekarskich za pośrednictwem systemów teleinformatycznych lub systemów łączności to istotny element telemedycyny. Tego rodzaju aktywność zawodowa lekarza podlega wszelkim wymogom związanym z prowadzeniem działalności, które określono w obowiązującym prawie, a w szczególności w ustawie o działalności leczniczej, w tym obowiązkowi wpisania do rejestru oraz w zakresie prowadzenia dokumentacji medycznej. Podczas zdalnego udzielania świadczeń zdrowotnych lekarza obowiązują wobec pacjenta takie same standardy jak przy tradycyjnym leczeniu, włączając w to wymóg należytej staranności oraz zgodności z aktualną wiedzą medyczną. Ze względu na brak bezpośredniego kontaktu z pacjentem spełnienie tych standardów może się okazać szczególnie wymagające.

Słowa kluczowe: telemedycyna, należyta staranność, systemy łączności

Folia Cardiologica 2018; 13, 5: 489-493

\section{Wstęp}

Jak definiuje ją Światowa Organizacja Zdrowia (WHO, World Health Organization), telemedycyna to świadczenie usług opieki zdrowotnej, w której kluczową rolę odgrywa rozłączność miejsca, przez wszystkie osoby wykonujące zawody medyczne, $z$ wykorzystaniem instrumentów służących wymianie istotnych informacji w celach diagnostycznych, leczniczych oraz zapobiegania chorobom i urazom, prowadzenia badań i ich oceny, zapewnienia, kontynuacji kształcenia pracowników służby zdrowia, czyli w celu poprawy zdrowia poszczególnych osób oraz tworzonych przez nie społeczności [1-3]. Wykorzystanie rozwiązań telemedycznych może stanowić istotne remedium na niektóre, spośród licznych, problemy systemowe w ochronie zdrowia. Tego rodzaju instrumenty mogą służyć rozwiązaniu problemów niedoboru kadr medycznych, prowadzą do ograniczenia zbędnych kosztów hospitalizacji i przyspieszaja proces diagnostyczny. Telemedycyna nie stanowi konkurencji dla medycyny tradycyjnej, a jest raczej narzędziem wspierającym prace personelu medycznego i działającym na korzyść pacjenta [4].

W Komunikacie Komisji do Parlamentu europejskiego definiuje się telemedycynę jako świadczenie usług zdrowotnych z wykorzystaniem technologii informacyjno-komunikacyjnych w sytuacji, gdy pracownik służby zdrowia i pacjent (lub dwaj pracownicy służby zdrowia) nie znajdują się w tym samym miejscu. Usługi telemedyczne wiążą się z przesyłaniem danych i informacji medycznych (jako tekstu, obrazu, dźwięku lub w innej formie), które są konieczne do działań prewencyjnych, diagnozy, leczenia i kontroli stanu zdrowia pacjenta [5]. W dokumencie tym, wśród korzyści związanych z telemedycyną, wskazuje się na poprawę dostępu do specjalistycznej opieki na obszarach, gdzie dostęp do opieki zdrowotnej jest utrudniony lub brakuje specjalistów. Usługi, takie jak teleradiologia i telekonsultacje, mogą się przyczynić do skrócenia list oczekujących, optymalizacji wykorzystania zasobów i przyrostu wydajności [5]. 
Telemedycyna nie znajduje zastosowania we wszystkich dziedzinach medycyny, ponieważ w pewnych przypadkach warunkiem prawidłowego rozpoznania lub diagnozy jest osobiste badanie pacjenta. Etap pierwotnej diagnozy pacjenta wydaje się zresztą newralgiczny, jako że ocena jego stanu zdrowia na podstawie wywiadu przeważnie musi być poprzedzona wszechstronnym badaniem przedmiotowym. Ponadto absolutna większość zabiegów medycznych wymaga bezpośredniego kontaktu z pacjentem, co wyklucza możliwość zdalnego udzielania świadczenia. Telemedycyna niesie ze sobą liczne ryzyka, zwłaszcza w kontekście bezpieczeństwa danych wrażliwych oraz obarczenia tego rodzaju usług ryzykiem utraty lub nieupoważnionego dostępu do danych [6]. Istotnym jest także ryzyko związane z błędem diagnostycznym, którego źródło może tkwić w braku bezpośredniego kontaktu z pacjentem, wskutek którego nastąpiło niewłaściwe lub niepełne przekazanie istotnych informacji lub doszło do jej zniekształcenia podczas zdalnego przekazu $[7,8]$.

\section{Wybrane podstawy prawne telemedycyny}

Zgodnie z przepisem artykułu 2 ustawy o zawodach lekarza i lekarza dentysty wykonywanie zawodu lekarza polega na udzielaniu przez osobę posiadającą wymagane kwalifikacje, potwierdzone odpowiednimi dokumentami, świadczeń zdrowotnych, a w szczególności: badaniu stanu zdrowia, rozpoznawaniu chorób i zapobieganiu im, leczeniu i rehabilitacji chorych, udzielaniu porad lekarskich, a także wydawaniu opinii i orzeczeń lekarskich. Lekarz może wykonywać te czynności także za pośrednictwem systemów teleinformatycznych lub systemów łączności. Zdanie to, formalnie sankcjonujące telemedycynę, ustawodawca wprowadził do ustawy zawodowej lekarskiej dopiero w roku 2015, natomiast w praktyce medycznej dużo wcześniej zaczęto rozwijać tę dyscyplinę. Rozwiązania legislacyjne potwierdziły jedynie, że telemedycyna jest legalną formą uprawiania zawodu lekarza, skoro zgodnie z aktualnym stanie wiedzy medycznej staje się w wielu przypadkach standardem postępowania.

Podobne przepisy, porządkujące zdalne udzielanie świadczeń zdrowotnych, znajdują się także w innych aktach prawnych z dziedziny ochrony zdrowia. W ustawie o działalności leczniczej jeden z przepisów stanowi, że działalność ta polega na udzielaniu świadczeń zdrowotnych, przy czym może się to odbywać za pośrednictwem systemów teleinformatycznych lub systemów łączności. Pielegnniarka i położna wykonują zawód z należytą starannością, zgodnie z zasadami etyki zawodowej, poszanowaniem praw pacjenta, dbałością o jego bezpieczeństwo, wykorzystując wskazania aktualnej wiedzy medycznej oraz pośrednictwo systemów teleinformatycznych lub systemów łączności. W ustawie o Państwowym Ratownictwie Medycznym już w 2007 roku wskazano, że podczas prowadzenia medycznych czynności ratunkowych kierujący akcją medyczną pozostaje w stałym kontakcie z dyspozytorem medycznym wskazanym przez głównego dyspozytora medycznego lub z głównym dyspozytorem medycznym.

Narodowy Fundusz Zdrowia, w zarządzeniu prezesa nr 127/2017/DSOZ z 19 grudnia 2017 roku w sprawie określenia warunków zawierania i realizacji umów w rodzaju świadczenia zdrowotne kontraktowane odrębnie, wprowadził do katalogu świadczeń dwa nowe zakresy świadczeń - telekonsylium kardiologiczne i telekonsylium geriatryczne. Telekonsylium kardiologiczne obejmuje wywiad, analizę zapisu elektrokardiograficznego (EKG), interpretację wyników badań oraz ustalenie planu leczenia. Porada w ramach telekonsylium geriatrycznego jest kierowana głównie do pacjentów po 65. roku życia, a jej zadanie to optymalizacja leczenia farmakologicznego.

\section{Obowiązki lekarza zdalnie leczącego pacjenta}

Kodeks etyki lekarskiej przewiduje w artykule 9, że lekarz może podejmować leczenie jedynie po uprzednim zbadaniu pacjenta. Wyjątki stanowią sytuacje, gdy porada lekarska może być udzielona wyłącznie na odległość. Przytoczone brzmienie jednej z zasad deontologicznych, chwalonych przez samorząd lekarski, pozostaje niespójne z przywołanymi przepisami prawa, które wprost sankcjonują prawną dopuszczalność zdalnego udzielania świadczeń zdrowotnych. Bezsprzecznie wiążący charakter obowiązujących norm prawnych nie pozostawia wątpliwości co do tego, że normy etycznie nie podążyły w tym zakresie nie tylko za medyczną rzeczywistością, ale również za ustawodawcą. Pierwszy człon przytoczonego artykułu, wedle którego podjęcie leczenia warunkuje uprzednie zbadanie pacjenta, mógłby być interpretowany w ten sposób, że wymagane badanie pacjenta odbywa się przy użyciu instrumentów zdalnych, gdyby nie drugie zdanie, które stanowi o wyjątkach w tym zakresie. Literalne brzmienie zdania drugiego wyklucza przyjęcie, że dotyczy ono wszystkich przypadków wykorzystania telemedycyny zgodnie z aktualną wiedzą medyczną, skoro w wielu sytuacjach udzielenie porady lekarskiej na odległość będzie wynikiem zgodnej woli lekarza i pacjenta, a nie przypadku obiektywnej konieczności udzielenia porady w takim trybie. Dla porządku ustawowego zasadnym wydaje się usunięcie istniejących w aktach prawnych rozbieżności w zakresie usankcjonowania telemedycyny. Stopień zaawansowania tej formy udzielania świadczeń zdrowotnych jest na tyle duży, że tego rodzaju rozbieżności nie powinny być rozstrzygane za pomocą norm usuwających konflikty między wzajemnie sprzecznymi przepisami, tylko nie powinny w ogóle występować.

Rozważając zagrożenia, jakie wiążą się z realizowaniem świadczeń zdrowotnych w tym trybie, wypada wskazać na ryzyko związane ze zniekształceniem obrazu dotyczącego 
aktualnego stanu zdrowia pacjenta $[9,10]$. Z pewnością możliwość osobistej rozmowy z pacjentem daje większy komfort w zakresie oceny jego stanu nie tylko na podstawie przekazywanych informacji, ale także na podstawie oceny wizualnej i badania palpacyjnego [11]. Specyfika określonych dziedzin medycyny wyklucza przez to praktyczna możliwość zastosowania rozwiązań zdalnych przy badaniu pacjenta [12]. Ograniczenie możliwości przekazywania danych dotyczących poszczególnych zmysłów wyklucza możliwość na przykład osłuchania serca pacjenta, które wciąż jest wykonywane „analogowo” z wykorzystaniem otoskopu (por. [13]). Wydaje się ponadto, że nie wszystkie reakcje pacjenta na bodźce możliwe są do uchwycenia w przypadku rozmowy przy wykorzystaniu komunikatorów zdalnych, co może wpływać na ocenę jego nieświadomych reakcji, łatwiej dostrzegalnych „gołym okiem” [14]. Jakość sprzętu medycznego, służącego do przekazywania na odległość obrazu i dźwięku, musi gwarantować odpowiedni standard przekazu, który zapewni staranną ocenę przekazywanych treści, umożliwiając ich adekwatną ocenę przez lekarza [15].

Na lekarzach ciąży ustawowy obowiązek wykonywania zawodu zgodnie ze wskazaniami aktualnej wiedzy medycznej, dostępnymi metodami i środkami zapobiegania, rozpoznawania i leczenia chorób, zgodnie z zasadami etyki zawodowej oraz z należytą starannością (art. 4 ustawy o zawodach lekarza i lekarza dentysty). Cytowany przepis odnosi się do staranności zawodowej lekarza, która powinna być należyta, właściwie dobrana do kwalifikacji danego lekarza (zespołu lekarzy), jego doświadczenia i sytuacji, w której udzielana jest pomoc potrzebującej osobie. Postępowanie lekarza w danej sytuacji należy oceniać z uwzględnieniem całokształtu okoliczności istniejących w chwili wykonywania zabiegu medycznego, a zwłaszcza tych danych, którymi lekarz dysponował albo mógł dysponować, mając na uwadze wymagania aktualnej wiedzy i nauki medycznej oraz powszechnie przyjętej praktyki lekarskiej.

\section{Elektroniczna dokumentacja medyczna w najbliższej perspektywie}

W rozporządzeniu ministra zdrowia z 8 maja 2018 roku w sprawie rodzajów elektronicznej dokumentacji medycznej wskazuje się, że do zakresu tej kategorii należą: informacja o rozpoznaniu choroby, problemu zdrowotnego lub urazu, wynikach przeprowadzonych badań, przyczynie odmowy przyjęcia do szpitala, udzielonych świadczeniach zdrowotnych oraz ewentualnych zaleceniach, informacja dla lekarza kierującego świadczeniobiorce do poradni specjalistycznej lub leczenia szpitalnego o rozpoznaniu, sposobie leczenia, rokowaniu, ordynowanych lekach, środkach spożywczych specjalnego przeznaczenia żywieniowego i wyrobach medycznych, w tym okresie ich stosowania i sposobie dawkowania oraz wyznaczonych wizytach kontrolnych, a także karta informacyjna z leczenia szpitalnego.

Dokumentacja medyczna wskazana powyżej może być prowadzona w postaci papierowej do 31 grudnia 2018 roku. Recepty mogą być wystawiane w postaci papierowej do 31 grudnia 2019 roku. Z kolei skierowania mogą być wystawiane w postaci papierowej do 31 grudnia 2020 roku. Dane zawarte w elektronicznej dokumentacji medycznej za pośrednictwem SIM udostępnia się od 1 stycznia 2021 roku. Usługodawcy są zobowiązani do zgłoszenia jednostce podległej ministrowi właściwemu do spraw zdrowia właściwej w zakresie systemów informacyjnych ochrony zdrowia gotowości podłączenia swoich systemów do Elektronicznej Platformy Gromadzenia, Analizy i Udostępnienia Zasobów Cyfrowych o Zdarzeniach Medycznych nie później niż do 31 grudnia 2018 roku w odniesieniu do recept, nie później niż do 30 czerwca 2019 roku - w odniesieniu do skierowań oraz nie później niż do 31 grudnia 2019 roku - w odniesieniu do wymiany elektronicznej dokumentacji medycznej, której kategorie wskazano w poprzednim akapicie [16, 17].

\section{Wnioski}

Artykuł 4 ustawy o zawodach lekarza i lekarza dentysty stanowi, że lekarz ma obowiązek wykonywać swój zawód zgodnie ze wskazaniami aktualnej wiedzy medycznej, dostępnymi mu metodami i środkami zapobiegania, rozpoznawania i leczenia chorób, zgodnie z zasadami etyki zawodowej oraz z należytą starannością. Artykuł 55 kodeksu etyki lekarskiej przewiduje, że powinnością każdego lekarza jest stałe uzupełnianie i doskonalenie swej wiedzy i umiejętności zawodowych. Bez wątpienia telemedycyna wpisuje się w kanon aktualnej wiedzy medycznej i może być traktowana jako jeden ze standardów postępowania medycznego [18-20]. Szczególnie jednak w tej dziedzinie zasadnym wydawałoby się normatywne określenie owego standardu postępowania, ponieważ przez jego pryzmat jest oceniany poziom staranności lekarza, który determinuje ewentualną winę w przypadku wystąpienia szkody. Nie wydaje się jednak, by w tym zakresie ustawodawca podążył za rozwojem wiedzy medycznej. Owszem, w odniesieniu do elektronicznej dokumentacji medycznej stosowne regulacje powstają, samoistnie określając obowiązujący w tym zakresie porządek prawny. Jednak w zakresie samego postępowania medycznego nie należy się spodziewać odgórnych wytycznych, skoro brakuje ich nawet w odniesieniu do standardowych dziedzin medycyny. Jak dotąd standardy postępowania medycznego określono jedynie w kilku zakresach świadczeń, takich jak położnictwo i ginekologia czy anestezjologia i intensywna terapia. W pozostałym zakresie pomocne są dowody oparte na badaniach naukowych (EBM, evidence-based medicine) oraz 
standardy branżowe. Tym większe znaczenie mają wówczas obowiązek samokształcenia oraz staranność w doborze metod diagnostycznych służących do zdalnego udzielania świadczeń zdrowotnych. Wciąż brakuje wielu przykładów rozwiązania sporów na tle błędów medycznych powstałych na skutek wykorzystania urządzeń do zdalnego udzielania świadczeń zdrowotnych i wynikających z pośredniego charakteru leczenia [21]. Zapewne tego rodzaju przypadki będą sukcesywnie występować, pozwalając na określenie quasi-precedensowego standardu zdalnego postępowania medycznego. Z pewnością istotne znaczenie w tym zakresie będą miały zakres i charakter zgody pacjenta, w którym będzie musiało zostać uwzględnione, w określonym zakresie, ryzyko związane z wykorzystaniem do badania lub leczenia środków zdalnego komunikowania się [22, 23]. Z pewnością jednak przyjęcie przez pacjenta związanego z tym ryzyka nie będzie usprawiedliwiać niestaranności czy braku wiedzy lekarza [24, 25]. Brak wiedzy stanowi winę lekarza. Wzorcem, do którego należy sięgać w odniesieniu do lekarza, jest wzorzec „dobrego fachowca”. Przyjmuje się pewien poziom fachowości, poniżej którego postępowanie lekarza należy ocenić ujemnie. Od lekarzy wymaga się wyższej staranności ze względu na podmiot ich zabiegów, którym jest człowiek, i skutki wadliwego leczenia - często nieodwracalne.

Aktualnie na etapie prac legislacyjnych jest rozporządzenie ministra zdrowia w sprawie standardów organizacyjnych opieki zdrowotnej dla podmiotów wykonujących działalność leczniczą w dziedzinie radiologii i diagnostyki obrazowej za pośrednictwem systemów teleinformatycznych. Jak wskazuje się w uzasadnieniu projektu, ma ono określać standardy organizacyjne opieki zdrowotnej dla podmiotów wykonujących działalność leczniczą w dziedzinie radiologii i diagnostyki obrazowej za pośrednictwem systemów teleinformatycznych. Przepisami ustawy z 9 października 2015 roku o zmianie ustawy o systemie informacji w ochronie zdrowia oraz niektórych innych ustaw (Dz. U. poz. 1991) wprowadzono do porządku prawnego rozwiązania ułatwiające udzielanie świadczeń zdrowotnych w modelu telemedycyny, co dało realną podstawę implementacji technologii informacyjno-komunikacyjnych do praktyki klinicznej.

\section{Konflikt interesów}

Autorka deklaruje brak konfliktu interesów.

\section{Abstract}

Providing medical care via data communication systems is an important element of telemedicine. This type of professional activity of a physician is subject to all the requirements defined in the applicable laws, in particular in the Act on Medical Activity. While providing telemedicine health services, the same standards as for traditional treatment appropriately apply, including the requirement of due diligence and compliance with current medical knowledge. Due to the absence of direct contact with a patient, compliance with these standards may prove particularly demanding.

Key words: telemedicine, ICT systems, communication systems

Folia Cardiologica 2018; 13, 5: 489-493

\section{Piśmiennictwo}

1. WHO, Telemedicine. Opportunities and development in Member States. Report on the second global survey on eHealth 2010.

2. Darkins A, Cary MA. Telemedicine and telehealth: principles, policies, performances and pitfalls. Springer, New York 2000.

3. Wootton R, Craig J, Patterson V. Introduction to telemedicine, second edition. The Royal Society of Medicine Press Ltd., London 2006.

4. Karkowski T. Telemedycyna i eHealth w sektorze opieki zdrowotnej. ABC. System Informacji Prawnej LEX Ochrona zdrowia.

5. Komunikat Komisji do Parlamentu europejskiego, Rady, Europejskiego komitetu ekonomiczno-społecznego oraz Komitetu regionów w sprawie korzyści telemedycyny dla pacjentów, systemów opieki zdrowotnej i społeczeństwa. https://eur-lex.europa.eu/legal-content/ /PL/TXT/?uri=CELEX\%3A52008DC0689 (06.11.2018).
6. Blackmon LA, Kaak HO, Ranseen J. Consumer satisfaction with telemedicine child psychiatry consultation in rural kentucky. Psychiatr Serv. 1997; 48(11): 1464-1466, doi: 10.1176/ps.48.11.1464, indexed in Pubmed: 9355177.

7. Edworthy SM. Telemedicine in developing countries may have more impact than in developed countries. BMJ. 2001; 323: 524, doi: 10.14217/9781848597563-5-en.

8. Wyrok Sądu Apelacyjnego we Wrocławiu z dnia 24 stycznia 2014 r. http://orzeczenia.wroclaw.sa.gov.pl/details/\$N/155000000000503_ _I_ACa_001370_2013_Uz_2014-02-18_001 (06.11.2018).

9. Tadeusiewicz R. Telemedycyna - nowe wyzwanie współczesnej nauki. Nauka. 2004; 3: 57-80. 
10. Roine R, Ohinmaa A, Hailey D. Assessing telemedicine: a systematic review of the literature. CMAJ. 2001; 165(6): 765-771, indexed in Pubmed: 11584564.

11. Jankowski M, Klimczak-Wieczorek A, Kloc M, Matuszewski M, Rozum J. Telemedycyna w Polsce. Możliwości i szanse rozwoju. Fundacja im. Lesława A. Pagi, Warszawa 2016: 1-20.

12. Siebert J, Rumiński J. Telemedycyna. FMR. 2007; 1(1): 1-10.

13. Nazarko-Ludwiczak E. Telemedycyna - przydatne narzędzie pracy i korzyść wizerunkowa. ABC. System Informacji Prawnej LEX Ochrona zdrowia.

14. Smith AC, Gray LC. Telemedicine across the ages. Med J Aust. 2009; 190(1): 15-19, indexed in Pubmed: 19120002.

15. Whitten PS, Mair FS, Haycox A, et al. Systematic review of cost effectiveness studies of telemedicine interventions. BMJ. 2002; 324(7351): 1434-1437, doi: 10.1136/bmj.324.7351.1434, indexed in Pubmed: 12065269.

16. Ustawa z dnia 28 kwietnia 2011 r. o systemie informacji w ochronie zdrowia. http://prawo.sejm.gov.pl/isap.nsf/DocDetails.xsp?id=W DU20111130657(06.11.2018).

17. Wąsik D. Ustawa o systemie informacji w ochronie zdrowia. Komentarz. Wolters Kluwer Polska, Gdańsk 2015.

18. Handschu R, Littmann R, Reulbach U, et al. Telemedicine in emergency evaluation of acute stroke: interrater agreement in remote video examination with a novel multimedia system. Stroke. 2003; 34(12): 2842-2846, doi: 10.1161/01.STR.0000102043.70312.E9, indexed in Pubmed: 14615620.
19. Czarnuch M, Grabowski M, Najbuk P, Kołtowski Ł, Balsam P, Pachocki J, Jaskiewicz M, Luba A. Telemedyczna Grupa Robocza. Otoczenie regulacyjne telemedycyny w Polsce - stan obecny i nowe otwarcie. DZP - Więcej niż prawo, Warszawa 2015.

20. Zundel KM. Telemedicine: history, applications, and impact on librarianship. Bull Med Libr Assoc. 1996; 84(1): 71-79, indexed in Pubmed: 8938332.

21. Stanberry B. Telemedicine: barriers and opportunities in the $21^{\text {st }}$ century. J Intern Med. 2000; 247(6): 615-628, doi: 10.1046/j.1365-2796.2000.00699.x, indexed in Pubmed: 10886483.

22. Bashshur RL, Shannon GW. History of telemedicine: evolution, context, and transformation. Healthc Inform Res. 2010; 16(1): 65-66, doi: 10.4258/hir.2010.16.1.65, indexed in Pubmed: 3089841.

23. Whitten PS, Mair FS, Haycox A, et al. Systematic review of cost effectiveness studies of telemedicine interventions. BMJ. 2002; 324(7351): 1434-1437, doi: 10.1136/bmj.324.7351.1434, indexed in Pubmed: 12065269.

24. Wootton R. Telemedicine in the national health service. J R Soc Med. 1998; 91(12): 614-621, doi: 10.1177/014107689809101202, indexed in Pubmed: 10730107.

25. Currell $R$, Urquhart $C$, Wainwright $P$, et al. Telemedicine versus face to face patient care: effects on professional practice and health care outcomes. Cochrane Database Syst Rev. 2000(2): CD002098, doi: 10.1002/14651858.CD002098, indexed in Pubmed: 10796678. 